\title{
Fungi Associated with Spring Dead Spot Reduces Freezing Resistance in Bermudagrass
}

\author{
J.L. Nus ${ }^{1}$ \\ Golf Course Superintendents Association of America, 1421 Research Park \\ Drive, Lawrence, KS 66049
}

\author{
K. Shashikumar ${ }^{2}$ \\ Department of Horticulture, Kansas State University, Manhattan, KS 66506
}

Additional index words. winter hardiness, differential thermal analysis, Leptosphaeria

korrae, Ophiospharella herpotricha, disease, winterkill, supercooling, exotherm

\begin{abstract}
Although the effect of cold winters on the severity of bermudagrass (Cynodon dactylon Pers.) spring dead spot (SDS) has been studied, information is needed concerning the effect of infection by fungi associated with SDS on the host's freezing resistance. A-22 bermudagrass was inoculated with Leptosphaeria korrae J. Walker \& A.M. Smith and Ophiospharella herpotricha (Fr.) J. Walker \& A.M Smith. Differential thermal analysis was used to monitor exotherm temperatures of healthy and $O$. herpotricha- and $L$. korraeinfected A-22 bermudagrass at 10-day intervals during 90 days of acclimation in cold chambers. Healthy bermudagrass crowns supercooled to an average of $-6.7 \mathrm{C}$ and fungiinfected crowns supercooled to an average of $\mathbf{- 4 . 8}$ and $-4.4 \mathrm{C}$, respectively. Healthy crown exotherm temperatures were significantly lower than those of fungi-infected bermudagrass crowns on all nine sampling dates. This result indicates that fungi-infected plants are more susceptible to cold damage.
\end{abstract}

Spring dead spot (SDS) is a serious disease of bermudagrass and its hybrid cultivars. Fungi associated with the disease include Gaeumannomyces graminis (Sacc.) Arx. and Oliver var. graminis, Leptosphaeria korrae, and Ophiospharella herpotricha. SDS severity increases with cold winters and management factors that reduce winter hardiness, delay fall dormancy, or promote early spring greenup (Lucas, 1980; McCarty and Lucas, 1989; Pair et al., 1986).

Plants survive subfreezing temperatures by tolerating cell dehydration caused by extracellular ice formation and supercooling to avoid freezing in certain critical tissues (Rajashekar and Burke, 1978).

McCarty et al. (1991) found that carbohydrate reserves are lower and that there is less regrowth following exposure to low temperature in G. graminis -infected berrnudagrass. It is unknown, however, whether SDS-causing fungi affect bermudagrass freezing. This research was conducted to test whether infection by $O$. herpotricha or $L$. korrae affects the

Received for publication 23 Mar. 1992. Accepted for publication 29 Oct. 1992. Contribution no. 92391-J of the Kansas State Agricultural Experiment Station. We express appreciation to Channa Rajashekar and Barry Harter for technical assistance with freezing procedures and to the Kansas Turfgrass Foundation for partially funding this project. The cost of publishing this paper was defrayed in part by payment of page charges. Under postal regulations this paper therefore must be hereby marked advertisement solely to indicate this fact. ${ }^{1}$ Technical Editor.

${ }^{2}$ Graduate student. capacity of bermudagrass to supercool to subfreezing temperatures.

During Summer 1989, A-22 bermudagrass sprigs were planted in 4-cm-diameter $\times 20$-cmdeep plastic containers (Cone-tainer Nursery, Canby, Ore.) containing a sterile 1 soil : 1 peat : 1 perlite mix (by volume). The soil was a Chase silty clay loam (fine, montmorillonitic, mesic Aquic Arduidoll). One gram of oat (Avena sativa L.) seed colonized by $O$. herpotricha or a Kentucky bluegrass (Poa pratensis L.) isolate of L. korrae (obtained from G. Worf, Univ. of Wisconsin) was placed uniformly in the upper $5 \mathrm{~cm}$ of the soil mixture before sprigging. Roots were allowed to grow through the inoculum. After the plants were established in the greenhouse ( 25 to $30 \mathrm{C}$ ) for 3 months, they were transferred to growth chambers maintained at $15 \mathrm{C}, 14$-h photoperiods, and $300 \pm 50 \mu \mathrm{mol} \cdot \mathrm{m}^{-2} \cdot \mathrm{s}^{-1}$ photosynthetic photon flux (PPF). Noninfected control plants were grown also.

After 1 month in the growth chambers, the containers were transferred to chambers at $4 \mathrm{C}$ under a similar PPF. Plants were grown at this temperature during the acclimation period, irrigated daily, and fertilized weekly with Hoagland's nutrient solution (Hoagland and Arnon, 1950). Samples with discolored roots and ectotrophic hyphae were removed, surfacesterilized, placed on potato dextrose agar acidified with lactic acid to $\mathrm{pH} 4.5$, and incubated in darkness. Fungal colonies producing a white, septate, colony mycelium that turned light tan to brown after 3 to 7 days were identified tentatively as $O$. herpotricha (Tisserat et al., 1989). The identity of both pathogens was confirmed by restricted frag- ment length polymorphism analysis, as described by Tisserat et al. (1991).

Freezing resistance of healthy and fungiinfected crowns was evaluated at 10-day intervals during 90 days of acclimation at $4 \mathrm{C}$ in the cold chamber. Freezing in healthy and diseased crowns was detected by differential thermal analysis (DTA) (Rajashekar et al., 1983). The DTA apparatus consisted of six thermoelectric modules that were made from Nand Pelements of the semiconductorbismuth telluride (Melcor, Trenton, N.J.). Each thermoelectric module was housed in a sample chamber and cooled in a bench-top freezer (Tenney Engineering, Union, N.J.) at a rate of 4 to $5 \mathrm{C} / \mathrm{h}$. Cooling and exotherm data collection were regulated using a microcomputer with a 12-bit analog-digital converter. For DTA, plants were cleaned to remove soil and plant debris and separated into individual crowns. Excess root and stem material was removed. A crown was defined as a rootless node containing several nonelongated lateral buds. A sampling unit consisted of five bermudagrass crowns wrapped in aluminum foil and placed on the ceramic surface of the thermoelectric modules. Sample temperature was monitored with a 0.51 -mm (24-gauge) type-T thermocouple. Two replicate samples each of healthy and L. korrae- and $O$. herpotricha -infected crowns were frozen during each sampling period. Data were analyzed using separate analysis of variance (Steel and Torrie, 1960) for each sampling date. Exotherm temperature means were separated using Duncan's multiple range test.

Healthy A-22 bermudagrass crowns had significantly lower exotherm temperatures (mean-6.7C) than $O$. herpotricha- or L. korraeinfected crowns (means 4.8 and $-4.0 \mathrm{C}$, respectively) on each of the nine sampling dates

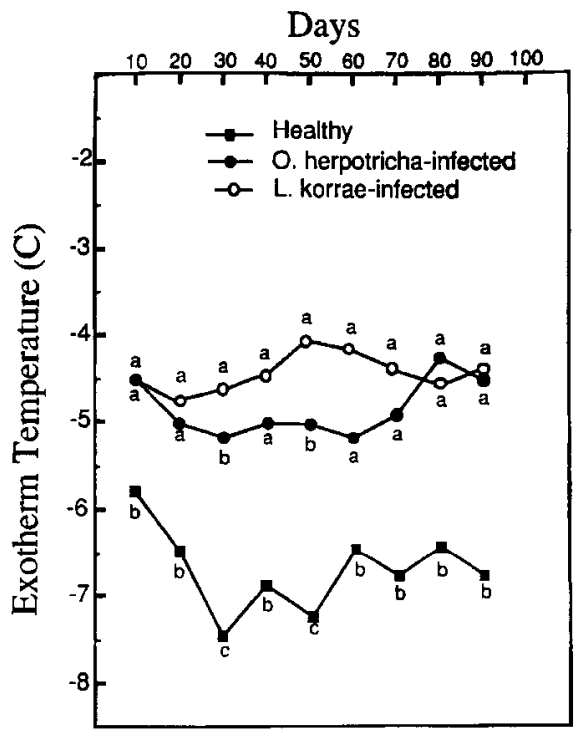

Fig. 1. Mean exotherm temperatures of healthy and O. herpotricha- and L. korrae-infected A-22 bermudagrass crowns. Each point represents the mean of two samples containing five crowns each. Means within sampling dates with different letters are significantly different at $P=0.05$, determined by Duncan's multiple range test. 
(Fig. 1). On two of the sampling dates, $O$. herpotricha -infected crowns had significantly lower exotherm temperatures than $L$. korraeinfected crowns. It is unknown whether $O$. herpotricha and $L$. korrae have ice-nucleating properties, ice-nucleating active bacteria are associated with these fungi (Lindow et al., 1978), or the increased exotherm temperature is the colligative consequence of lower soluble carbohydrate levels. The degree of supercooling depends on effective nucleators and the freezing point of the solution, in this case, cell sap (Blum, 1988). Fitter and Hay (1987) pointed out that depressing the freezing point of cell sap with increased soluble sugars and other osmotica can protect frost-sensitive species from frost damage in warm climates. McCarty et al. (1991) attributed reduced regrowth of fungi-infected bermudagrass following exposure to low temperatures to lower carbohydrate levels than those found in healthy controls.

We do not know to what extent these exotherm data established in cold chambers reflect field conditions. In the laboratory, killing temperature often can be defined narrowly for a single plant or plant part. In the field, however, the actual killing temperature is much harder to define (Burke and Stushnoff, 1979). Turfgrass organs vary in cold hardiness (Rajashekar et al., 1983) and whole plants usually supercool only a few degrees, whereas certain plant parts may supercool considerably more (Hale and Orcutt, 1987).

If fungi-infected crowns have decreased supercooling in the field, then the physical disruption and dehydration associated with freezing (Kacperska-Palacz, 1978) would occur sooner than in healthy crowns. These processes would increase the host's mortality and the spring symptomology associated with SDS.

\section{Literature Cited}

Blum, A. 1988. Plant breeding for stress environments. CRC Press, Boca Raton, Fla.

Burke, M.J. and C. Stushnoff. 1979. Frost hardiness: A discussion of possible molecular causes of injury with particular reference to deep supercooling of water, p. 197-225. In: H. Mussell and R.C. Staples (eds.). Stress physiology, in crop plants. Wiley \& Sons, New York.

Fitter, A.H. and R.K.M. Hay. 1987. Environmental physiology of plants. Academic, New York.

Hale, M.G. and D.M. Orcutt. 1987. The physiology of plants under stress. Wiley \&Sons, New York.

Hoagland, D.R. and D.I. Anton. 1950. The water culture method for growing plants without soil. Univ. of California, Berkeley, Circ. 347.

Kacperska-Palacz, A. 1978. Mechanisms of cold acclimation in herbaceous plants, p. 139-152. In: P.H. Li and A. Sakai (eds.). Plant cold hardiness and freezing stress, mechanisms, and crop implications. Academic, New York.

Lindow, SE., D.C. Amy, and C.D. Upper. 1978. The role of bacterial ice nuclei in frost injury to sensitive plants, p. 249-263. In: P.H. Li and A.
Sakai (eds.). Plant cold hardiness and freezing stress. mechanisms. and crop implications. Academic, New York.

Lucas, L.T. 1980. Spring dead spot of bermudagrass, p. 183-187. In: B.G. Joyner and P.O. Larsen (eds.). Advances in turfgrass pathology. Harcourt Brace Jovanovich, Duluth, Minn.

McCarty, L.B., J.M. DiPaola, and L.T. Lucas. 1991. Regrowth of bermudagrass infected with spring dead spot following low temperature exposure. Crop Sci. 31:182-184.

McCarty, L.B. and L.T. Lucas. 1989. Gaeumannomyces graminis associated with spring dead spot of bermudagrass in the southeastern United States. Plant Dis. 73:659-661.

Pair, J.C., F.J. Crowe, and W.G. Willis. 1986. Transmission of spring dead spot disease by turf/soil cores. Plant Dis. 70:877-878.

Rajashekar, C. and M.J. Burke. 1978. The occurrence of deep undercooling in the genera Pyrus, Prunus, and Rosa: A preliminary report, p. 213225. In: P.H. Li and A. Sakai (eds.). Plant cold hardiness and freezing stress, mechanisms, and crop implications. Academic, New York.

Rajashekar, C.B., D. Tao, and P.H. Li. 1983. Freezing resistance and cold acclimation in turfgrasses. HortScience 18:91-93.

Steel, R.G.D. and J.H. Torrie. 1960. Principles and procedures of statistics. McGraw-Hill, New York.

Tisserat. N.A.. S.H. Hulbert. and A. Nus. 1991. Identification of Leptospharia korrae by cloned DNA probes. Phytopathology 81:917-921.

Tisserat, N.A., J.C. Pair, and A. Nus. 1989. Ophiospharella herpotricha, a cause of spring dead spot of bermudagrass in Kansas. Plant Dis. 73:933-937. 